\title{
A CRANIOMETRIC COMPARISON OF HOLOCENE POPULATIONS OF MYOTIS MYSTACINUS (KUHL, 1817) AND M. BRANDTII (EVERSMANN, 1845) (CHIROPTERA, MAMMALIA)
}

\author{
by \\ P. RYBAR \\ Regional Centre for the Protection of Historical Monuments and Nature Conservation in the East Bohemian \\ Region, Pardubice, Czechoslovakia
}

\begin{abstract}
This paper presents the results of an analysis of about four hundred skulls of Myotis mystacinus and $M$. brandtii of the Holocene age from the Záskocie Cave (Central Slovakia). A review of criteria for species determination is presented, including a new criterion concerning the morphology of $\mathrm{P}^{4}$ roots, as well as the results of a statistical survey of skull dimensions and correlation and regression analyses. The author concludes that the above mentioned bats are not sibling species, but that they belong to different subgenera of the genus Myotis.
\end{abstract}

\section{INTRODUCTION}

Until recently, the Brandt's Bat (Myotis brandtii) was considered to be just a subspecies of the Whiskered Bat ( $M$. mystacinus). It was only in 1958 that Topál speculated, proceeding to the basis of a study of the morphology of the baculum (os penis) about the possibility that the two forms might constitute two separate species. A number of authors (cf. Baagøe, 1973) have dealt with this problem. After some initial doubts (cf. Hanák, 1965), the existence of two separate forms was confirmed (Hanák, 1970, 1971a; Vlček, 1970; Gauckler \& Kraus, 1970). The sympatric occurrence of the species all the year round and the subsequently found morphological differences provided the final proof.

If the recognition of Myotis brandtii was "an unexpected result of detailed taxonomic research of a common species" (Hanák \& Danko, 1975: 33), a minute taxonomic analysis of a large amount of material is necessary for final evaluation. However, most authors based their conclu- sions on studies dealing with only a few dozen individuals at the most; only Baagøe (1973) and Ruprecht (1974) presented analyses of about one hundred individuals of both species.

During an investigation in the Liptov karst (Central Slovakia, C.S.S.R.) I found 396 skulls of Myotis mystacinus and $M$. brandtii, i.e. material very suitable for taxonomic evaluation using statistical methods. The results of my work also provide a contribution towards a better understanding of the Central European Holocene bat fauna.

\section{MATERIAL AND METHODS}

The Holocene material comes from Czechoslovakia's deepest cave, Záskočie. This cave is situated on a hillside of Mt. Krakova hola in the Lower Tatra Mts. (opening is at $1,332 \mathrm{~m}$ above sea level); the animal remains were collected from the surface of cave fills in 1973. Among 615 skulls of eight species which were collected there, $M$. brandtii $(282$ skulls, i.e. $45.8 \%+107$ mandibles) and $M$. mystacinus (114 skulls, i.e. $18.5 \%+53$ mandibles) were the two most frequently represented taxa. The facial parts of fragmental skulls (rostra) constituted about $25 \%$ of the sample, the remainder were relatively complete skulls. In the majority of cases, only the bullae ossae, incisors, canines and first two premolars were missing.

Skulls and mandibles were fixed in a gelatine solution and 23 dimensions were measured using calipers under a binocular microscope. The ac- 
curacy of $0.05 \mathrm{~mm}$ was adequate for the degree of preservation of the material and also for the statistical validity of the sample sizes.

About nine thousand measurements were analyzed using an Odra 1204 computer. The arithmetic means (including their $95 \%$ confidence limits), range and standard deviations were calculated. Interspecific differences of the arithmetic means were examined by $F$ - and Student's $t$-tests. To determine the correlation ratio of the skull dimensions, the correlation coefficient $r$ was established $(0=$ linear independence, $0.10-0.39$ $=$ slight dependence, $0.40-0.69=$ medium dependence, $\geqslant 0.70$ = strong dependence); hundredfold of its square, the index of determination indicates the influence of the argument on the function in per cent. Conforming with Sigmund (1964b), the $95 \%$ confidence limits of the correlation coefficient were established. At the same time, the null hypothesis was tested, whether or not the correlation coefficients originate from random sampling. In order to determine the allometric ratios, linear regressions were calculated as well as the coefficients $a$ and $b$ of the regression lines and their $95 \%$ confidence limits. Carrying out the linearity regression test was considered as a precondition for all computations.
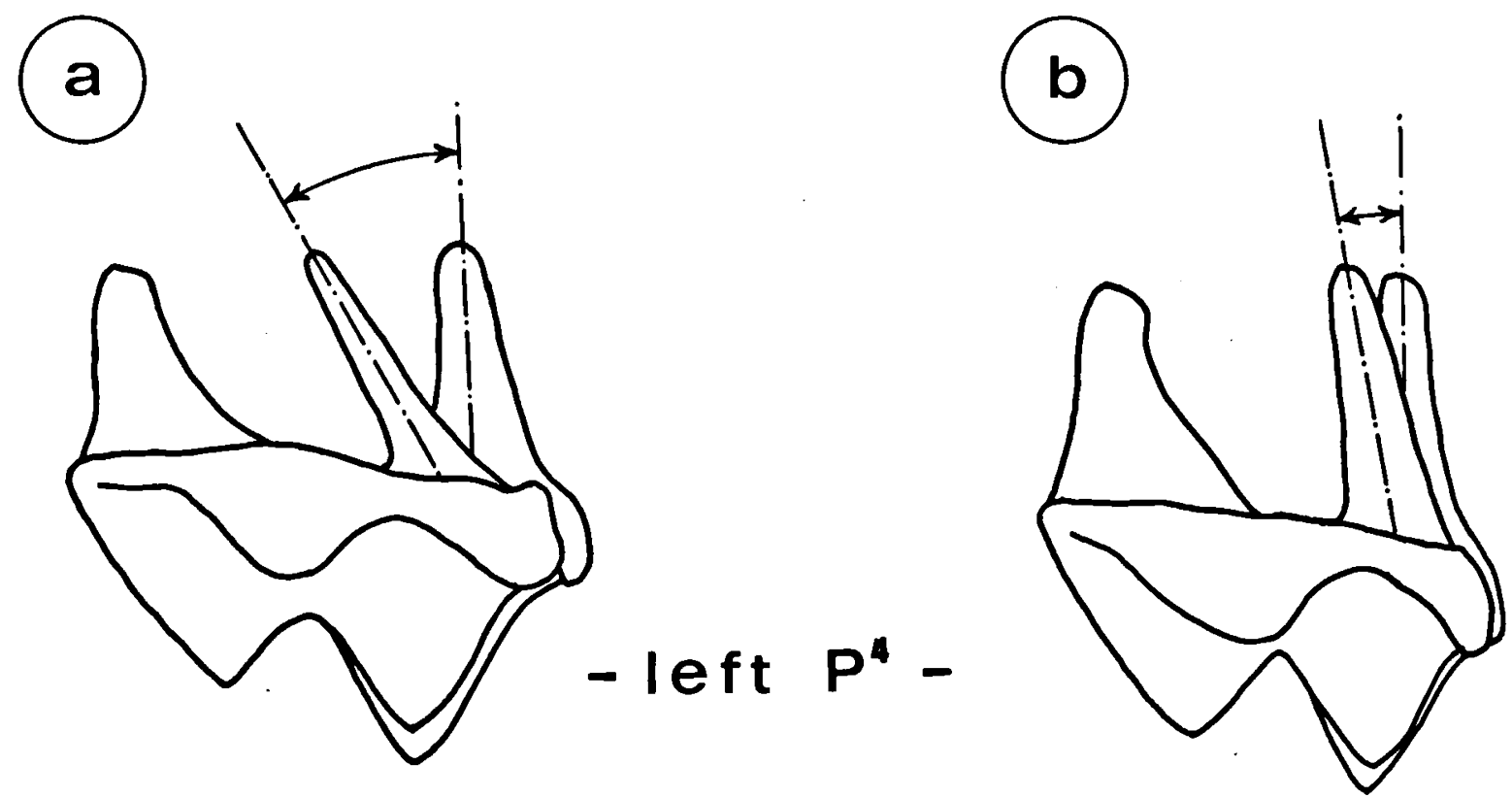

Fig. 1. The morphology of $\mathrm{P}^{4}$ roots as a criterion for species determination: (a) Myotis

\section{RESULTS AND DISCUSSION}

A reliable specific identification of the skulls was a first problem. This matter requires detailed analysis and evaluation of a large portion of the material. Because of this I will deal with species determination first.

\section{Dimensions. -}

Formerly, only the skull dimensions were used as a criterion for the separation of the two forms, particularly using the condylobasal length: specimens with a condylobasal length over $13.4 \mathrm{~mm}$ had been considered as brandtii and under 13.3 mm as mystacinus (cf. Hanák, 1965). In later papers more critical values were presented, but some bats could not be determined in this manner (Baagøe, 1973; Ruprecht, 1974; etc.). In my opinion (cf. table I) condylobasal lengths ranging between $12.00-13.00 \mathrm{~mm}$ indicate $M$. mystacinus, and those from 13.30 to $14.40 \mathrm{~mm} M$. brandtii; the intermediate zone (13.05-13.25 mm) includes about $5 \%$ of the total material. Slight overlap occurs also in the total length and width of the skull and in the infraorbital width (cf. Baagøe, 1973).

\section{Species determination}

$$
\text { mystacinus; (b) M. brandtii. }
$$


Morphology. -

Relatively slender skulls and evident bending of their frontal parts occur in both species. Skull shape helps identifying a major portion of the material: $M$. mystacinus has a large concavity of the frontal profile and its braincase is elongated (egg-shaped) from the dorsal view; the profile of the $M$. brandtii skull is rather flat and elongated, the braincase is shaped like a polygon inserted in a circle.

Teeth. -

The standard criteria - i.e. the ratio of $P_{2}$ and $P_{3}$ sizes $\left(P_{3}\right.$ are rather lower than $P_{2}$ in $M$. mystacinus, see Gauckler \& Kraus, 1970; Hanák, 1970, 1971a), or their position (inward suppression of $\mathrm{P}_{3}$ in $M$. mystacinus) - are not suitable for fossil material with fragmental denture. Some authors (Stubbe \& Chotolchu, 1968; Gauckler \& Kraus, 1970; Baagøe, 1973) consider the occurrence of small protoconules on the frontal edge of upper molars to be characteristic of $M$. brandtii, others (e.g. Hanák, 1971a) deny the reliability of these criteria. These characters are not suitable for critical identification especially of fragmented fossil material. Also the secondary cone on the inner margin of $\mathrm{P}^{4}$ (according to some authors a reliable determining criterion; cf. Topál, 1963; Gauckler \& Kraus, 1970; Hanák, 1970, 1971a) is relevant only to the determination of some $M$. brandtii; in some samples of the population it is inconspicuous while a portion of $M$. mystacinus has a relatively pronounced cone.

In the course of my research I have found a new criterion for species identification, viz. the morphology of $\mathrm{P}^{4}$ roots (see fig. 1). The usefulness of this feature is based on the fact, that the roots are protected from outside influences (cf. the abrasion of the teeth crowns). The last of the upper premolars has two roots lying on the bucal side and one on the lingual side. From the frontal (rostral) view, the first bucal root of $M$. brandtii appears only slightly thinner in comparison with the second one and is slightly bent to the lingual side (i.e. axes of both roots are nearly parallel). By contrast, the first root of $\mathrm{P}^{4}$ in $M$. mystacinus is noticeably thinner than the second one, and its axis is bent to the lingual side. The $\mathrm{P}^{4}$ of $M$. mystacinus can be extracted from the upper jaw much more easily than in $M$. brandtii.

One basic criterion in the genus Myotis is the occurrence of 38 teeth $\left(\frac{2133}{3133}\right)$. However, in the material of $M$. brandtii two anomalies occur: oligodonty (absence of both $\mathrm{P}^{2}$ ) and polydonty (supernumerary $\mathrm{C}$ on both sides of the upper jaw). Oligodonty in female $M$. mystacinus was noted by Baagøe (1973).

\section{Skull dimensions}

Skull dimensions of the collection from the Záskočie Cave are given in table I. The skull of $M$. brandtii appears to be generally larger, although some overlap occurs with $M$. mystacinus.

Up to now, significant differences were established only for the total skull length, condylobasal length, width of skull, infraorbital width and length of the mandible. Therefore, most authors consider the dimensional differences between the two species to be minor. My results show, however, that the arithmetical means of these dimensions are highly significantly different (in most cases $p<0.001 !$ ); the length of $\mathrm{M}^{1}-\mathrm{M}^{3}$ being the only exception (see table I).

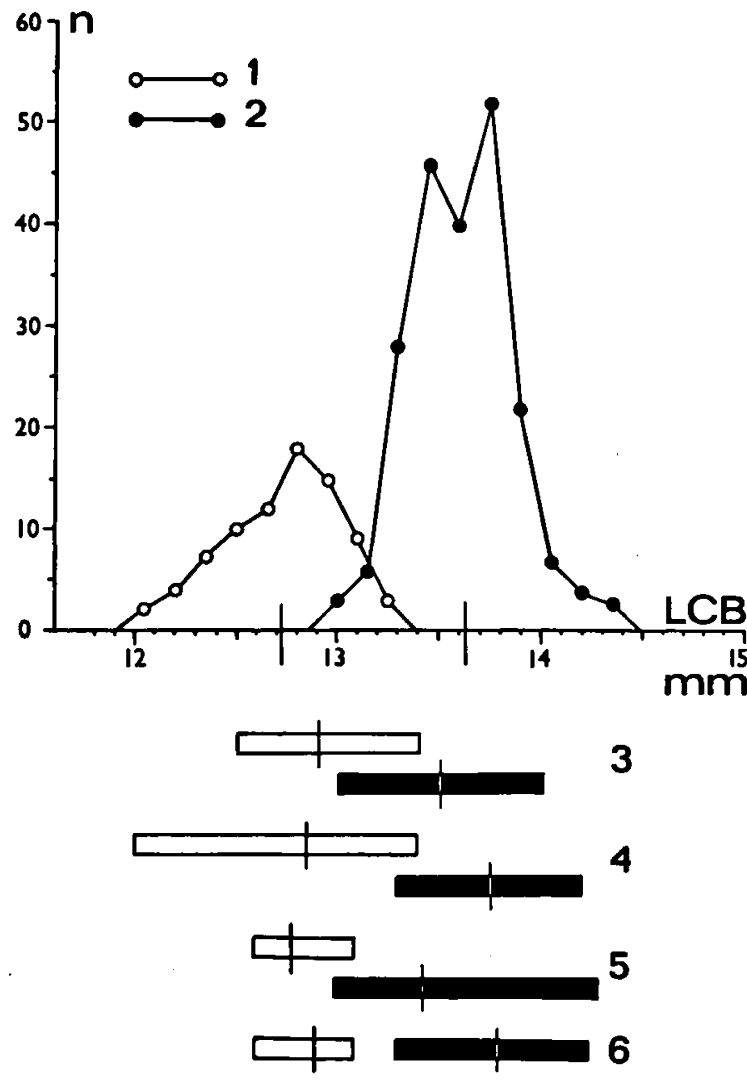

Fig. 2. Condylobasal length: (1) Myotis mystacinus and (2) $M$. brandtii from Záskočie Cave; (3) Gauckler \& Kraus, 1970; (4) Hanák, 1971a; (5) Baagøe, 1973; (6) Ruprecht, 1974; (open columns $=M$. mystacinus, black ones $=M$. brandtii $)$. 
Table I. The statistical analysis of skull dimensions.

\begin{tabular}{|c|c|c|c|c|c|}
\hline \multirow[b]{2}{*}{ Dimension (abbreviation) } & \multicolumn{5}{|c|}{ Myotis mystacinus } \\
\hline & $n$ & $\overline{\boldsymbol{x}}$ & $\begin{array}{l}95 \% \text { confidence } \\
\text { limits of } \bar{x}\end{array}$ & Range & S.D. \\
\hline Total length of skull (LCr) & 74 & 13.354 & $13.288-13.420$ & $12.55-13.80$ & 0.286 \\
\hline Condylobasal length (LCB) & 80 & 12.715 & $12.653-12.777$ & $12.00-13.25$ & 0.277 \\
\hline Basal length ( $\mathrm{LBCr}$ ) & 80 & 11.369 & $11.311-11.428$ & $10.75-11.80$ & 0.263 \\
\hline Width of braincase (LaN) & 70 & 6.986 & $6.942-7.031$ & $6.60-7.30$ & 0.185 \\
\hline Zygomatic width (LaZ) & 48 & 8.100 & $8.031--8.170$ & $7.20-8.45$ & 0.239 \\
\hline Rostral width $(\mathrm{C}-\mathrm{C})$ & 95 & 3.179 & $3.152-3.206$ & $2.85-3.45$ & 0.130 \\
\hline Interorbital width (LaI) & 93 & 3.555 & $3.529-3.580$ & $3.25-3.85$ & 0.124 \\
\hline Infraorbital width (LaInf) & 98 & 3.268 & $3.239-3.330$ & $2.90-3.55$ & 0.142 \\
\hline Length of palate - including spina nasalis ( $\mathrm{LPa})$ & 86 & 7.318 & $7.281-7.355$ & $6.85-7.65$ & 0.173 \\
\hline Alveolar length of $I^{1}-M^{3}$ & 100 & 5.992 & $5.964-6.019$ & $5.60-6.30$ & 0.140 \\
\hline Alveolar length of $\mathrm{C}-\mathrm{M}^{3}$ & 105 & 4.889 & $4.867-4.910$ & $4.60-5.20$ & 0.111 \\
\hline Alveolar length of $\mathrm{P}^{1}-\mathrm{M}^{3}$ & 106 & 4.145 & $4.123-4.168$ & $3.80-4.45$ & 0.182 \\
\hline Crown length of $\mathrm{P}^{4}-\mathrm{M}^{3}$ & 46 & 3.687 & $3.661-3.713$ & $3.50-3.85$ & 0.086 \\
\hline Crown length of $\mathbf{M}^{1}-\mathbf{M}^{3}$ & 34 & 3.127 & $3.040-3.213$ & $2.85-3.20$ & 0.249 \\
\hline Height of braincase (AN) & 71 & 4.835 & $4.801-4.868$ & $4.50-5.25$ & 0.140 \\
\hline Alveolar width of $\mathrm{M}^{3}-\mathrm{M}^{3}$ & 94 & 5.098 & $5.060-5.136$ & $4.75-5.45$ & 0.184 \\
\hline Condylar length of mandible (LMa) & 21 & 9.598 & $9.498-9.698$ & $9.20-9.90$ & 0.219 \\
\hline Alveolar length of $I_{1}-M_{3}$ & 25 & 6.420 & $6.359-6.482$ & $6.00-6.65$ & 0.148 \\
\hline Alveolar length of $\mathrm{C}-\mathrm{M}_{3}$ & 26 & 5.456 & $5.401-5.510$ & $5.15-5.65$ & 0.135 \\
\hline Alveolar length of $P_{1}-M_{3}$ & 25 & 4.806 & $4.754-4.858$ & $4.55-5.10$ & 0.126 \\
\hline Crown length of $P_{4}-M_{3}$ & 3 & 4.083 & $3.704-4.463$ & $3.95-4.25$ & 0.153 \\
\hline Crown length of $M_{1}-M_{3}$ & 7 & 3.429 & $3.313-3.545$ & $3.25-3.60$ & 0.125 \\
\hline Height of processus coronoideus (APC) & 19 & 2.747 & $2.708-2.787$ & $2.60-2.90$ & 0.082 \\
\hline
\end{tabular}

Measurements in $\mathrm{mm}$.

The range of the skull dimensions of both species from the Záskočie Cave was similar to the recently published data for other Holocene and recent populations (Woloszyn, 1970; Baagøe, 1973; Ruprecht, 1974).

In view of the extensive material available, bimodal curves of frequency distribution could be established for a number of dimensions (e.g. condylobasal length, $\mathbf{M}^{3}-\mathbf{M}^{3}, \mathrm{C}-\mathrm{M}^{3}$, etc.). Their character remains constant even if classification grouping is made. This bimodality is probably due to sexual dimorphism, although Baagøe (1973) found smaller differences between the sexes (fig. 2; see also phylogenetic remarks).

Also remarkable were the statistically significant interspecific differences in variance of $z y$ gomatic width, rostral width, alveolar length of $\mathrm{C}-\mathrm{M}^{3}$ and alveolar width of $\mathrm{M}^{3}-\mathrm{M}^{3}$. A greater variance was found in $M$. brandtii.

\section{Relation between the skull dimensions}

References to the mutual relations of the skull proportions in $M$. mystacinus and $M$. brandtii are very infrequent. Sigmund $(1965,1966)$ presents some somatic and skeleton allometries, but his results refer to $M$. mystacinus sensu lato, i.e. including $M$. brandtii. Only Baagøe (1973) provides some values for reliably identified material, useful for systematics. However, the importance of the allometries under discussion must not be overlooked, because they represent the results of selective processes in the course of evolution (Sigmund, 1964a, 1966) and thus contribute towards solving some evolutionary and other problems.

Correlation and regression analyses for 32 (and 64) pairs of values were examined of the Záskočie material. The most important results of correlation analysis are given in table II. A moderate to strong degree of interdependence of the dimensions under comparison could be established in most cases. Only a slight correlation is evident between the condylobasal length and the height of braincase in both species.

An important interspecific difference was established between the ratio of interorbital width and infraorbital width: a significantly lower correlation occurs in $M$. mystacinus than in $M$. brandtii. Furthermore, while in $M$. mystacinus the 
Table I, continued.

\begin{tabular}{|c|c|c|c|c|c|c|c|c|}
\hline \multicolumn{5}{|c|}{ Myotis brandtii } & \multicolumn{2}{|c|}{$F$-test } & \multicolumn{2}{|c|}{$t$-test } \\
\hline$n$ & $\bar{x}$ & $\begin{array}{l}95 \% \text { confidence } \\
\text { limits of } \dot{x}\end{array}$ & Range & S.D. & $F$ & $\begin{array}{l}\text { significance } \\
\text { level }\end{array}$ & $t$ & $\begin{array}{l}\text { significance } \\
\text { level }\end{array}$ \\
\hline 187 & 14.255 & $14.216-14.295$ & $13.60-15.10$ & 0.273 & 1.098 & 0.6103 & 23.72 & $0.0000 * * *$ \\
\hline 209 & 13.615 & $13.581-13.649$ & $13.05-14.40$ & 0.250 & 1.229 & 0.2511 & 26.54 & $0.0000^{* * *}$ \\
\hline 215 & 12.159 & $12.126-12.191$ & $11.40-12.85$ & 0.244 & 1.163 & 0.3964 & 24.16 & $0.0000^{* * *}$ \\
\hline 184 & 7.560 & $7.536-7.584$ & $7.15-8.00$ & 0.167 & 1.235 & 0.2712 & 23.74 & $0.0000 * * *$ \\
\hline 121 & 8.725 & $8.691-8.759$ & $8.30-9.10$ & 0.188 & 1.618 & $0.0386^{*}$ & 16.23 & $0.0000^{* * *}$ \\
\hline 257 & 3.365 & $3.351-3.378$ & $3.10-3.95$ & 0.110 & 1.405 & $0.0389^{*}$ & 12.35 & $0.0000^{* * *}$ \\
\hline 241 & 3.816 & $3.801-3.831$ & $3.55-4.15$ & 0.118 & 1.094 & 0.5836 & 17.86 & $0.0000^{* * *}$ \\
\hline 268 & 3.693 & $3.678-3.708$ & $3.40-4.10$ & 0.125 & 1.281 & 0.1267 & 27.70 & $0.0000^{* * *}$ \\
\hline 244 & 7.740 & $7.718-7.763$ & $7.25-8.20$ & 0.179 & 1.065 & 0.7477 & 19.00 & $0.0000^{* * *}$ \\
\hline 271 & 6.406 & $6.389-6.423$ & $6.05-6.80$ & 0.141 & 1.026 & 0.8976 & 25.10 & $0.0000 * * *$ \\
\hline 278 & 5.229 & $5.213-5.245$ & $4.85-5.85$ & 0.139 & 1.587 & $0.0068^{* *}$ & 24.94 & $0.0000^{* * *}$ \\
\hline 278 & 4.434 & $4.420-4.447$ & $4.20-4.80$ & 0.113 & 1.088 & 0.5824 & 22.04 & $0.0000 * * *$ \\
\hline 230 & 3.858 & $3.845-3.875$ & $3.55-4.10$ & 0.099 & 1.336 & 0.2450 & 10.86 & $0.0000 * * *$ \\
\hline 209 & 3.186 & $3.170-3.202$ & $2.90-3.45$ & 0.116 & 4.629 & $0.0000^{* * *}$ & 1.37 & 0.1801 \\
\hline 187 & 4.912 & $4.892-4.933$ & $4.55-5.40$ & 0.140 & 1.005 & 0.9580 & 3.99 & $0.0001^{* * *}$ \\
\hline 264 & 5.350 & $5.332-5.368$ & $5.00-5.80$ & 0.148 & 1.542 & $0.0082^{* *}$ & 12.00 & $0.0000^{* * *}$ \\
\hline 48 & 10.296 & $10.239-10.352$ & $9.90-10.70$ & 0.195 & 1.264 & 0.4992 & 13.17 & $0.0000^{* * *}$ \\
\hline 54 & 6.773 & $6.734-6.812$ & $6.50-7.20$ & 0.142 & 1.094 & 0.7637 & 10.15 & $0.0000^{* * *}$ \\
\hline 55 & 5.732 & $5.699-5.765$ & $5.45-6.05$ & 0.123 & 1.208 & 0.5515 & 9.14 & $0.0000 * * *$ \\
\hline 55 & 5.056 & $5.022-5.091$ & $4.85-5.35$ & 0.126 & 1.002 & 1.0000 & 8.23 & $0.0000 * * *$ \\
\hline 18 & 4.233 & $4.182-4.285$ & $4.00-4.40$ & 0.104 & 2.178 & 0.2956 & 2.18 & $0.0422^{*}$ \\
\hline 28 & 3.605 & $3.552-3.659$ & $3.45-4.50$ & 0.138 & 1.206 & 0.8845 & 3.09 & $0.0041 * *$ \\
\hline 50 & 2.975 & $2.942-3.008$ & $2.75-3.20$ & 0.116 & 1.985 & 0.1127 & 7.81 & $0.0000 * * *$ \\
\hline
\end{tabular}

$*=p<0.05 ; * *=p<0.01 ; * * *=p<0.001$.

correlation ratios of $\mathbf{M}^{1}-\mathrm{M}^{3}$ to $\mathbf{P}^{4}-\mathbf{M}^{3}$ (or $\mathbf{C}-\mathbf{M}^{3}$ ) are not significant, in $M$. brandtii higher correlations of $\mathbf{M}^{1}-\mathbf{M}^{3}$ to $\mathbf{P}^{4}-\mathbf{M}^{3}$ and still higher of $\mathbf{M}^{1}-\mathbf{M}^{3}$ to $\mathrm{C}_{-\mathrm{M}^{3}}$ are characteristic. Probably, this can be considered to be a result of the phylogenetic development of the $\mathrm{P}^{2}-\mathrm{P}^{3}$ zone during the Holocene.

Table II also presents some of the results of the regression analysis. The interspecific transposition of regression lines could be established in most cases (see also fig. 3). Like in sibling species (cf. Sachlová, 1966), the regression lines of longitudinal dimensions are very nearly parallel and not significantly different $\left(I^{1}-M^{3} / L C B, I_{1}-M_{3}\right.$ /LMa, C-M, / LMa). However, the important difference in skull shape influences the more substantial differences between the allometric ratios of longitudinal proportions to latitudinal ones, mutual ratios of latitudinal proportions and the ratio of the height of the skull to the condylobasal length (significant difference of parallel regression lines of $\mathrm{LaN} / \mathrm{LCB}, \mathrm{LaZ} / \mathrm{LCB}$, LaZ/LaI, AN/LCB and significantly unparalelled regression lines for $\mathrm{LaInf} / \mathrm{LaI}$ and $\mathrm{M}^{3} \cdot \mathrm{M}^{3} / \mathrm{LPa}$ ), i.e., in $M$. brandtii the longer skulls are relatively more slender at rostral parts, but they have relatively higher and wider braincases.

\section{Phylogenetic remarks}

According to current opinion, $M$. mystacinus is a younger evolutionary species and its evolution is closely connected with an older species $M$. brandtii. This view of its origin has never been explicitly stated, although the notion seems to be implied in several papers (e.g. Hanák, 1971b; Baagøe, 1973). The presumption, that $M$. mystacinus is a more advanced species is substantiated by indisputable facts:

- Morphology of the teeth, above all the more advanced reduction of $P_{3}$. (The progressive tentendency in the genus Myotis has its source in the reduction of the rostral part of the skull including the teeth, above all the premolars - Miller \& Allen, 1928; Kuzjakin, 1950; Woloszyn, 1969.)

- Recent (cf. Baagøe, 1973) as well as historic distribution of the species in Central Europe $(M$. brandtii occurred in the Pleistocene, $M$. mystacinus appears later, during the Holocene - WoYoszyn, 1970; Hanák, 1971b; Schaefer, 1974). 
Table II. The correlation and regression analysis of skull measurements.

\begin{tabular}{|c|c|c|c|c|c|c|}
\hline & & & & Myotis myst & inus & \\
\hline & & & & & Linear regre & $\gamma^{\prime}=\alpha+b x$ \\
\hline $\begin{array}{c}\text { Dim } \\
\text { Function } \\
(y)\end{array}$ & $\begin{array}{l}\text { Asions } \\
\qquad(x)\end{array}$ & $\boldsymbol{N}$ & $\begin{array}{l}r \\
95 \% \text { confidence } \\
\text { limits of } r\end{array}$ & $\begin{array}{c}\text { index of } \\
\text { determination } \\
(\%)\end{array}$ & $\begin{array}{l}a \\
95 \% \text { confidence } \\
\text { limits of } a\end{array}$ & $\begin{array}{c}b \\
95 \% \text { confidence } \\
\text { limits of } b\end{array}$ \\
\hline LaN & LCB & 65 & $\begin{array}{c}0.553 \\
0.362-0.705\end{array}$ & 30.62 & $\begin{array}{c}2.383 \\
0.635-4.130\end{array}$ & $\begin{array}{c}0.363 \\
0.225-0.500\end{array}$ \\
\hline $\mathbf{L a Z}$ & LCB & 45 & $\begin{array}{c}0.564 \\
0.330-0.739\end{array}$ & 31.80 & $\begin{array}{c}1.652 \\
-1.252-4.556\end{array}$ & $\begin{array}{c}0.508 \\
0.279-0.737\end{array}$ \\
\hline $\mathrm{LPa}$ & LCB & 75 & $\begin{array}{c}0.724 \\
0.598-0.818\end{array}$ & 52.42 & $\begin{array}{c}1.154 \\
-0.214-2.523\end{array}$ & $\begin{array}{c}0.484 \\
0.376-0.591\end{array}$ \\
\hline $\mathrm{I}^{1}-\mathrm{M}^{3}$ & LCB & 79 & $\begin{array}{c}0.771 \\
0.665-0.849\end{array}$ & 59.39 & $\begin{array}{c}0.858 \\
-0.105-1.820\end{array}$ & $\begin{array}{c}0.403 \\
0.327-0.478\end{array}$ \\
\hline $\mathrm{C}-\mathrm{M}^{3}$ & LCB & 79 & $\begin{array}{c}0.658 \\
0.515-0.769\end{array}$ & 43.33 & $\begin{array}{c}1.325 \\
0.399-2.250\end{array}$ & $\begin{array}{c}0.280 \\
0.207-0.353\end{array}$ \\
\hline $\mathrm{C}-\mathrm{M}^{3}$ & $I^{1}-M^{3}$ & 100 & $\begin{array}{c}0.750 \\
0.651-0.826\end{array}$ & 56.22 & $\begin{array}{c}1.299 \\
0.664-1.935\end{array}$ & $\begin{array}{c}0.599 \\
0.493-0.705\end{array}$ \\
\hline AN & LCB & 67 & $\begin{array}{c}0.270 \\
0.034-0.481\end{array}$ & 7.31 & $\begin{array}{c}3.079 \\
1.526-4.632\end{array}$ & $\begin{array}{c}0.139 \\
0.016-0.261\end{array}$ \\
\hline $\mathrm{LaZ}$ & LaI & 47 & $\begin{array}{c}0.365 \\
0.091-0.593\end{array}$ & 13.34 & $\begin{array}{c}5.683 \\
3.836-7.530\end{array}$ & $\begin{array}{c}0.678 \\
0.159-1.592\end{array}$ \\
\hline Lalnf & LaI & 88 & $\begin{array}{c}0.290 \\
0.088-0.472\end{array}$ & 8.42 & $\begin{array}{c}2.054 \\
1.201-2.908\end{array}$ & $\begin{array}{c}0.340 \\
0.099-0.580\end{array}$ \\
\hline$M^{3}-M^{3}$ & $\mathbf{L P a}$ & 29 & $\begin{array}{c}0.523 \\
0.344-0.669\end{array}$ & 27.31 & $\begin{array}{c}1.037 \\
-0.466-2.541\end{array}$ & $\begin{array}{c}0.555 \\
0.349-0.760\end{array}$ \\
\hline$M^{1}-M^{3}$ & $C-M^{3}$ & 34 & nonsignificant correlation & - & - & - \\
\hline$P^{4}-M^{3}$ & $M^{1}-M^{3}$ & 34 & nonsignificant correlation & - & - & - \\
\hline$I_{1}-M_{3}$ & LMa & $2 i$ & $\begin{array}{c}0.754 \\
0.493-0.899\end{array}$ & 56.89 & $\begin{array}{c}1.132 \\
-1.077-3.340\end{array}$ & $\begin{array}{c}0.550 \\
0.320-0.781\end{array}$ \\
\hline $\mathrm{C}-\mathrm{M}_{3}$ & LMa & 21 & $\begin{array}{c}0.790 \\
0.557-0.914\end{array}$ & 62.35 & $\begin{array}{c}0.610 \\
-1.194-2.414\end{array}$ & $\begin{array}{c}0.504 \\
0.316-0.691\end{array}$ \\
\hline$I_{1}-M_{3}$ & $\mathrm{C}-\mathrm{M}_{3}$ & 25 & $\begin{array}{c}0.852 \\
0.698-0.935\end{array}$ & 72.60 & $\begin{array}{c}1.206 \\
-0.176-2.588\end{array}$ & $\begin{array}{c}0.957 \\
0.704-1.211\end{array}$ \\
\hline$P_{4}-M_{3}$ & $M_{1}-M_{3}$ & 3 & - & - & - & - \\
\hline APC & LMa & 18 & $\begin{array}{c}0.486 \\
0.038-0.782\end{array}$ & 23.57 & $\begin{array}{c}0.970 \\
-0.729-2.669\end{array}$ & $\begin{array}{c}0.185 \\
0.008-0.362\end{array}$ \\
\hline
\end{tabular}

All correlations are significant at the $5 \%$ level of significance.

However, at the same time, the following facts must not be overlooked:

- In older forms a stabilization of variability in dimensions, morphology, etc. occurs. However, some skull dimensions of $M$. brandtii (cf. table I) are significantly more variable than comparable $M$. mystacinus measurements.

- The correlation between some dentition measurements points to a progressive development of morphology in $M$. brandtii during the Holocene. It is also possible that the conspicuous bimodal character of frequency curves of some skull measurements was not due to sexual dimorphism but reflects the above mentioned development (cf. Myotis bechsteini - Rybáŕ, 1976).

- Significant differences were found in some allometries (see continuation of table II) and not, as usually found in sibling species, merely a transposition of regression lines.

- Some sources (Topál, 1958; Vlček, 1970; Baagøe, 1973) give important differences in os penis morphology, which do not correspond to sibling species.

These contradictions would seem to indicate the 
Table II, continued. On the right hand side a comparison of allometric ratios is given (i.e. the linear regressions $y^{\prime}=a+b x$ ) in Myotis mystacinus and $M$. brandtil.

\begin{tabular}{|c|c|c|c|c|c|c|c|c|}
\hline \multicolumn{5}{|c|}{ Myotis brandtii } & \multicolumn{2}{|c|}{$\begin{array}{l}t \text {-test for identity of two } \\
\text { regression çoefficients } b \\
\end{array}$} & \multicolumn{2}{|c|}{$\begin{array}{l}t \text {-test for identity of } \\
\text { two linear regressions }\end{array}$} \\
\hline$N$ & $\begin{array}{c}r \\
95 \% \text { confidence } \\
\text { limits of } r\end{array}$ & $\begin{array}{c}\text { index of } \\
\text { determination } \\
(\%)\end{array}$ & $\begin{array}{l}\text { Linear regres } \\
a \\
95 \% \text { confidence } \\
\text { limits of } a\end{array}$ & $\begin{array}{c}\text { n } y^{\prime}=a+b x \\
b \\
95 \% \text { confidence } \\
\text { limits of } b\end{array}$ & $t$ & $\begin{array}{c}\text { significance } \\
\text { level }\end{array}$ & $t$ & $\begin{array}{l}\text { significance } \\
\text { level }\end{array}$ \\
\hline 172 & $\begin{array}{c}0.594 \\
0.489-0.684\end{array}$ & 35.32 & $\begin{array}{c}2.071 \\
0.946-3.196\end{array}$ & $\begin{array}{c}0.403 \\
0.320-0.486\end{array}$ & 0,5207 & 0.6031 & 5.430 & $0.0000^{* * *}$ \\
\hline 114 & 0.441 & 19.48 & 3.973 & 0.350 & 1.291 & 0.1986 & 4.234 & $0.0000 * * *$ \\
\hline 199 & $\begin{array}{c}0.282-0.580 \\
0.821 \\
0.770-0.862\end{array}$ & 67.35 & $\begin{array}{c}2.165-5.782 \\
0.001 \\
-0.757-0.759\end{array}$ & $\begin{array}{c}0.217-0.483 \\
0.569 \\
0.513-0.625\end{array}$ & 1.397 & 0.1650 & 1.976 & $0.0482 *$ \\
\hline 208 & $\begin{array}{c}0.787 \\
0.730-0.834\end{array}$ & 61.95 & $\begin{array}{c}0.350 \\
-0.302-1.003\end{array}$ & $\begin{array}{c}0.445 \\
0.397-0.493\end{array}$ & 0.9462 & 0.3449 & 1.602 & 0.1102 \\
\hline 209 & $\begin{array}{c}0.613 \\
0.521-0.692\end{array}$ & 37.54 & $\begin{array}{c}0.617 \\
-0.199-1.434\end{array}$ & $\begin{array}{c}0.339 \\
0.279-0.399\end{array}$ & 1.239 & 0.2171 & 2.586 & $0.0097^{* *}$ \\
\hline 271 & $\begin{array}{c}0.710 \\
0.647-0.765\end{array}$ & 50.45 & $\begin{array}{c}0.845 \\
0.324-1.367\end{array}$ & $\begin{array}{c}0.684 \\
0.603-0.766\end{array}$ & 1.255 & 0.2106 & 4.073 & $0.0000^{* * *}$ \\
\hline 181 & $\begin{array}{c}0.343 \\
0.208-0.466\end{array}$ & 11.74 & $\begin{array}{c}2.325 \\
1.278-3.373\end{array}$ & $\begin{array}{c}0.190 \\
0.113-0.267\end{array}$ & 0.7180 & 0.4734 & 2.442 & $0.0153^{*}$ \\
\hline 117 & $\begin{array}{c}0.487 \\
0.336-0.615\end{array}$ & 23.67 & $\begin{array}{c}5.627 \\
4.600-6.654\end{array}$ & $\begin{array}{c}0.812 \\
0.542-1.082\end{array}$ & 0.4602 & 0.6468 & 9.053 & $0.0000^{* * *}$ \\
\hline 235 & $\begin{array}{c}0.596 \\
0.507-0.673\end{array}$ & 35.46 & $\begin{array}{c}1.290 \\
0.872-1.709\end{array}$ & $\begin{array}{c}0.630 \\
0.520-0.740\end{array}$ & 2.183 & $0.0309^{*}$ & - & - \\
\hline 238 & $\begin{array}{c}0.353 \\
0.237-0.460\end{array}$ & 12.45 & $\begin{array}{c}2.997 \\
2.198-3.797\end{array}$ & $\begin{array}{c}0.304 \\
0.200-0.407\end{array}$ & 2.312 & $0.0215^{*}$ & - & - \\
\hline 209 & $\begin{array}{c}0.299 \\
0.171-0.418\end{array}$ & 8.92 & $\begin{array}{c}1.852 \\
1.267-2.436\end{array}$ & $\begin{array}{c}0.255 \\
0.143-0.366\end{array}$ & - & - & - & - \\
\hline 208 & $\begin{array}{c}0.559 \\
0.459-0.647\end{array}$ & 31.24 & $\begin{array}{c}2.216 \\
1.171-3.261\end{array}$ & $\begin{array}{c}0.230 \\
0.154-0.307\end{array}$ & - & - & - & - \\
\hline 48 & $\begin{array}{c}0.704 \\
0.531-0.826\end{array}$ & 49.61 & $\begin{array}{c}1.366 \\
-0.252-0.298\end{array}$ & $\begin{array}{c}0.525 \\
0.368-0.682\end{array}$ & 0.1889 & 0.8507 & 0.2642 & 0.7924 \\
\hline 48 & $\begin{array}{c}0.653 \\
0.458-0.793\end{array}$ & 42.64 & $\begin{array}{c}1.450 \\
-0.256-2.926\end{array}$ & $\begin{array}{c}0.416 \\
0.273-0.560\end{array}$ & 0.7400 & 0.4619 & 0.3776 & 0.7069 \\
\hline 54 & $\begin{array}{c}0.812 \\
0.699-0.889\end{array}$ & 65.93 & $\begin{array}{c}1.346 \\
0.260-2.432\end{array}$ & $\begin{array}{c}0.946 \\
0.756-1.135\end{array}$ & 0.0696 & 0.9447 & 2.744 & $0.0076^{* *}$ \\
\hline 15 & $\begin{array}{c}0.819 \\
0.549-0.941\end{array}$ & 67.08 & $\begin{array}{c}2.310 \\
1.490-3.129\end{array}$ & $\begin{array}{c}0.537 \\
0.312-0.763\end{array}$ & - & - & - & - \\
\hline 48 & $\begin{array}{c}0.362 \\
0.091-0.589\end{array}$ & 13.13 & $\begin{array}{c}0.716 \\
-1.007-2.440\end{array}$ & $\begin{array}{c}0.219 \\
0.052-0.387\end{array}$ & 0.2459 & 0.8066 & 1.488 & 0.1418 \\
\hline
\end{tabular}

$*=p<0.05 ; * *=p<0.01 ; * * * p<0.001$.

existence of a separate phylogenetic development of the two species. Thus, it may be necessary to exclude the species $M$. brandtii from the subgenus Selysius Bonaparte, 1841, to which $M$. mystacinus belongs. Naturally, it would be hardly possible to present the definitive solution of the subgenus determination of $M$. brandtii within the framework of the present paper. Nevertheless, some facts - e.g. the high frequency of protoconules on the $\mathrm{M}^{1-3}$ (cf. Tate, 1941) and the statistical analysis of the os penis dimensions (Vlček, 1970) - would seem to indicate that a relationship might exist to $M$. daubentonii (Kuhl, 1817), i.e. to the subgenus Leuconoe Boie, 1830.

\section{SUMMARY}

This paper presents the results of a systematic survey of 114 skulls and 53 mandibles of Myotis mystacinus and 282 skulls and 107 mandibles of $M$. brandtii collected in the Záskočie Cave, Slovakia, C.S.S.R.

1. The morphology and proportions of skulls and 


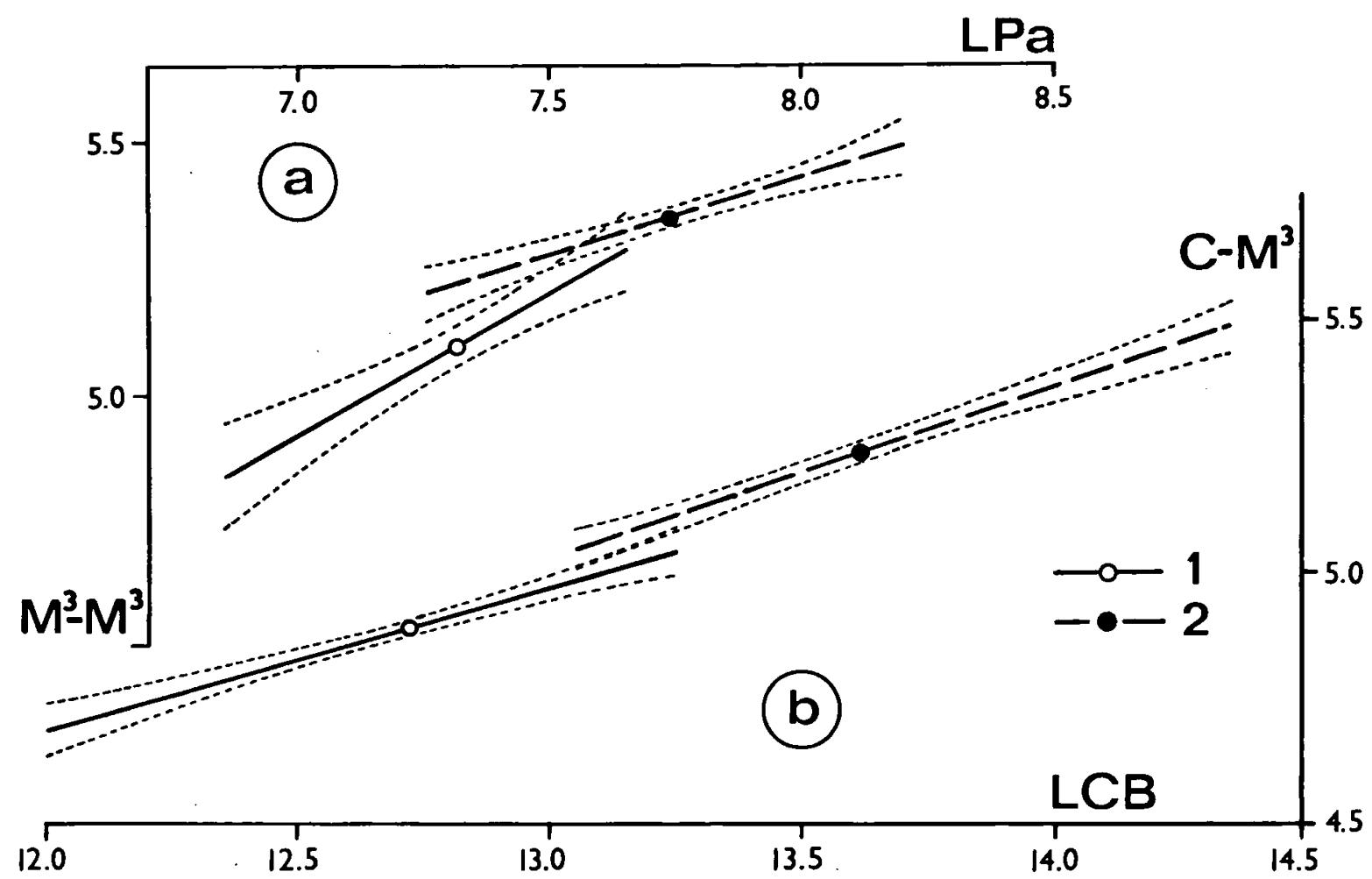

Fig. 3. Allometries of skull proportions in Myotis mystacinus (1) and $M$. brandtii (2) including their $95 \%$ confidence limits: (a) alveolar width of $\mathrm{M}^{3}-\mathrm{M}^{3}$ as the function of length of the palate (an example of unparallel regression lines); (b) alveolar length of $\mathrm{C}-\mathrm{M}^{3}$ as the function of condylobasal length (an example of significantly different parallel regression lines). All measurements in $\mathrm{mm}$.

mandibles, frequency of protoconules on the upper molars, size ratio of the premolars or the degree of development of the secondary cone on $\mathrm{P}^{4}$ were determined and were found then to be adequate only for identifying part of the material under consideration. A new discriminative criterion, based on the $\mathrm{P}^{4}$ roots morphology is proposed.

2. The results of the statistical analysis of skull dimensions are presented in table I. Although overlap between species occurs, arithmetic means (with the exception of the crown length of upper molars) are significantly different. A significantly greater variance was established in case of some dimensions in $M$. brandtii as compared to M. mystacinus.

3 . The results of the correlation and regression analysis (table II) concern the interspecific differences in the allometries of latitudinal dimensions of skulls.

4. A contradiction was found between the geologically older age of $M$. brandtii and some of its evolutionary advanced features (in comparison with $M$. mystacinus). This may indicate that $M$. brandtii and $M$. mystacinus are not sibling species, but that they each belong to a different subgenus: $M$. mystacinus to Selysius, $M$. brandtii probably to Leuconoe.

\section{ACKNOWLEDGEMENTS}

The author wishes to express his most heartfelt thanks to Mr. P. Hipman and Mrs. H. Kynclová, amateur speleologists of Zvolen, Slovakia, without whose kind help it would have hardly been possible to carry out the necessary fieldwork. Special thanks are also due to Ing. L. Strnad, CSc., Dipl. math. H. Skalská and Ing. S. Hekal for their kind cooperation in the course of the statistical analysis of the material. Author's thanks are also due to Mr. P. Mirejovsky and Dr. R. E. Stebbings for their help with the English translation of the manuscript. 


\section{LITERATURE}

BАAGøE, H. J., 1973. Taxonomy of two sibling species of bats in Scandinavia, Myotis mystacinus and Myotis brandtii (Chiroptera). Vidensk. Meddr. dansk naturh. Foren., 136 : 191-216.

GaUCKLER, A. \& M. Kraus, 1970. Kennzeichen und Verbreitung von Myotis brandti (Eversmann, 1845). Z. Säugetierk., 35 (2) : 113-124.

HANAK, V., 1965. Zur Systematik der Bartfledermaus Myotis mystacinus Kuhl, 1819 und über das Vorkommen von Myotis ikonnikovi Ognev, 1912 in Europa. Věst. čst. Spol. zool., 29 (4) : 353-367.

,- 1970 . Notes on the distribution and systematics of Myotis mystacinus Kuhl, 1819. Bijdr. Dierk., $40(1): 40-44$.

-, 1971a. Myotis brandtii (Eversmann, 1845) (Vespertilionidae, Chiroptera) in der Tschechoslowakei. Věst. čsl. Spol. zool., $35(3)$ : 175-185.

—, 1971b. Naši netopýrì. [Our bats]. Ziva, Praha, 19 (3) : 112-113.

HANÁ, V. \& S. DANKo, 1975. Netopýr obrovský (Nyctalus lasiopterus) - nový člen naši savči fauny. [Nyctalus lasiopterus - a new member of our mammal fauna]. Ziva, Praha, 23 (1) : 33-35.

KuZjakin, A. P., 1950. Letuchie myshi. [Bats] : $1-443$ (Sovetskaya Nauka, Moscow).

Miller, G. S. \& G. M. Allen, 1928. The American bats of the genera Myotis and Pizonyx. Bull. U.S. natn. Mus., 144 : i-viii, $1-218$.

RUPRECHT, A. L., 1974. The occurrence of Myotis brandtii (Eversmann, 1845) in Poland. Acta theriol., 19 (6) : 81-90.

RYBÁk, P., 1976. Contribution to the analysis of Quaternary populations of Myotis bechsteini, with a description of $\mathbf{M}$. bechsteini intermedius ssp. nov. Zool. listy, 25 (1) : 13-26.

SACHLOVA, D., 1966. Mezidruhové allometrické vztahy u rodu Plecotus (Microchiroptera). (Interspezifische allometrische Beziehungen der Gattung Plecotus (Microchiroptera)). Lynx, $6: 153-159$.

SChAEFER, H., 1974. Zur Faunengeschichte der Fledermäuse in der Hohen Tatra. Bonn. zool. Beitr., 24 (4) : 342-354.

SigmUND, L., 1964a. Relatives Wachstum und intraspezifische Allometrie der Grossmausohr (Myotis myotis Borkh.). Acta Univ. Carol. (Biologica), 1964 (3) : 235-303.

-, 1964b. Zur Methodik der Allometrieforschung. Věst. čsl. Spol. zool., 28 (4) : 380—384.

-, 1965. Grössenkorrelierte Proportionsunterschiede bei Fledermäusen der Gattung Myotis (Microchiroptera). Věst. čsl. Spol. zool., 29 (4) : 300-305.

-, 1966. Mezidruhové allometrické vztahy rodu Myotis Kaup, 1829 (Microchiroptera). (Interspezifische allometrische Beziehungen der Gattung Myotis (Microchiroptera)). Lynx, $6: 139-143$.

Stubbe, M. \& N. ChотоlсhU, 1968. Zur Säugetierfauna der Mongolei. Ergebnisse der Mongolisch-Deutschen Biologischen Expeditionen seit 1962, Nr. 30. Mitt. 20ol. Mus. Berl., 44 (1) : 5-121.

TATE, G. H. H., 1941. Results of the Archbold Expeditions. No. 39. A review of the genus Myotis (Chiroptera) of Eurasia, with special reference to species occurring in the East Indies. Bull. Am. Mus. nat. Hist., 78 (8) : 537-565.

TopAL, G., 1958. Morphological studies on the os penis of bats in the Carpathian Basin. Annls. hist.-nat. Mus. natn. hung., $50: 331-342$.

-, 1963. The bats of a Lower Pleistocene site from Mt. Kövesvárad near Répáshuta, Hungary. Annls. hist.-nat. Mus. natn. hung., $55: 143-154$.

VLČEK, M., 1970. Morfologie bakula netopýrú rodu Myotis. (Die Morphologie des Bakulum bei Fledermäusen der Gattung Myotis). Práce a studie-Přir., Pardubice, 2 : 97-127.

Wokoszyn, B. W., 1969. The Postglacial fauna of bats (Chiroptera) from the caves of Tatra Mts. Act. Congr. int. Spéléol., 4 (4-5) : 277-280.

,- 1970 . Holoceńska fauna nietoperzy (Chiroptera) z jaskyń tatrzaniskich. (The Holocene chiropteran fauna from the Tatra caves). Folia quatern., 35 : 1--76. 